\title{
Recommended sheep husbandry model and body weights of Morkaraman lambs in Muş province*
}

\author{
Turgut Aygün ${ }^{1 *}$ (อ), Hasan Çelikyürek² (0) \\ ${ }^{1}$ Van Yüzüncü Yıl University, Faculty of Agriculture, Department of Animal Science, Van, Turkey \\ ${ }^{2}$ Van Yüzüncü Yıl University, Vocational High School, Gevaş, Van, Turkey
}

\author{
Article History \\ Received: 18 December 2019 \\ Accepted: 20 July 2020
}

\section{*Corresponding Author \\ taygun@yyu.edu.tr}

\section{Key words}

Birth weight, husbandry model, Morkaraman, Muş province, sheep husbandry

\begin{abstract}
This research was carried out in order to determine some reproductive traits, the birth and the weaning weight and daily live weight gain of Morkaraman sheep in different farms of Muş province. The data used in this study was one year data of 2019 year obtained from a total of 28 sheep farms in Muş province. The mean for birth weight and 90th day weaning weight were calculated as $3.79 \pm 0.01$ and $29.30 \pm 0.10 \mathrm{~kg}$. The average daily live weight gain of lambs was found $272.8 \pm 0.01 \mathrm{~g}$ between birth and 90th day. Means for some reproductive traits as lambing rate, infertility rate, survival rate at 90th day weaaning, fecundity, and litter size were found as $92.2 \%, 7.8 \%, 97 \%, 1.11$, and 1.21 , respectively. Effect of birth type and dam age on birth and weaning weight and daily live weight gain was found to be statistically significant $(p<0.001)$. Effect of gender on birth $(p<0.001)$ and weaning weight $(p<0.05)$ was found to be statistically significant. The results of this research have shown that source of variation observed for birth and weaning weight in Morkaraman sheep may be the genetic and the environmental. As a result, it has been recommended to perform the improvement studies in mutton production from Morkaraman sheep and growth features can be used as a breeding criterion to improve meat yield.
\end{abstract}

\section{Introduction}

Sheep husbandry is an industrial sector that they transforms the natural vegetation cover pasture not used in the agriculture into the products such as meat, milk and, wool. There are breeds such as Akkaraman, Morkaraman, Awassi, Dağııç, Kıvırcık, and Karayaka among local sheep breeds of Turkey [12]. During recent years, sheep breeding has gained increasing popularity in Turkey.

The majority of sheep production in Turkey are carried out in extensive or semi-intensive systems. Muş city in located at East Anatolia region of Turkey is important for sheep production. The most of sheep breeds reared in Turkey are characterized as rough-mixed wool genotypes and their wools are usually used to carpet, blanket, quilt and weaving socks. There are the stock breeding systems, the trashumance husbandry, and the nomadic small ruminant husbandry in Muş province. Morkaraman sheep breed represents $21.5 \%$ of sheep breeds in Turkey. This breed is widely raised in the east of the country. Traits of Morkaraman sheep breed such as the herd and the maternal instinct are good. They are resistant to cold. They have also the ability to adapt to living conditions and poor environmental conditions. Their tails are fatty. The fat tail is used as an energy source during the long and insufficient winter feeding period [9]. This breed is bred for the production of wool as well as for meat production [6]. Lifetime weight-age relationship has become subjects of major interest of animal scientists and producers, due to the economic importance of mature weight, rate of maturing and related characteristics. Early estimation of these parameters can be of importance for selection purposes given their association with other traits and the economy of production [5]. Arslan et al. [1] reported that Morkaraman and Corriedale $x$ Morkaraman $\mathrm{F}_{1}$ lambs had birth weights of 3.41 and $3.85 \mathrm{~kg}$ respectively; weaning weights 21.99 and $21.65 \mathrm{~kg}$ (at the age of 90 days); found daily body weight increases from birth to breastfeeding as 206 and $198 \mathrm{~g}$.

In the highland sheep husbandry, sheep flocks are removed to the highlands with cool and plenty of grassy 
plains by pressing hot and dry towards the end of spring. For a period of 3-5 months, sheep remain in control by shepherds in the highland. After the weather cools down, sheep go back to the villages or the farms in the plain. Sheep herds usually consist of 300 to 500 heads. Sheep herds are taken away the summer ranges by grazing or by road transport [3]. The husbandry of small ruminats in this region has been adapted to regional differences, and has been characterized by the prominence of different applications. In the highland sheep husbandry, sheep flocks are removed to the highlands with cool and plenty of grassy plains by pressing hot and dry towards the end of spring.

This research was carried out in order to determine some reproductive traits, the birth and the weaning weight and daily live weight gain of Morkaraman sheep in different farms of Muş province. In addition, the importance of Morkaraman sheep breed, a significant genetic resource in Muş province has been emphasized in this paper.

\section{Materials and Methods}

\section{Research area}

Muş province is located on the Eastern Anatolia region of Turkey. Its surface area is $8196 \mathrm{~km}^{2}$. Its sea level height (altitude) is 1.350 meters. Average annual minimum and maximum temperatures of the region ranges from $-29 \stackrel{\circ}{\circ}$ to $+37 \stackrel{\circ}{\circ}$, respectively. It snows too much in the winter months in Muş province. Sheep are on the pasture for 5-6 months of the year in Muş province of Eastern Anatolia in Turkey.

\section{Animal material}

The data used in this study was one year data of 2019 year obtained from a total of 28 sheep farms in Muş province. The animal material consisted of a total of 5610 head of Morkaraman lambs including in different farms. Birth weights of lambs were taken within the first 24 hours after birth. Lambs were weighed by using electronic bascule at birth and weaning period (Figure 1 and 2).

\section{Statistical analysis}

Birth and weaning weight and daily live weight gain were analyzed using covariance analysis design. The statistical model based can be written as follows:

$$
Y_{i j k l}=\mu+a_{i}+b_{j}+c_{k}+e_{i j k l}
$$

Where;

$Y_{i j k l}=$ Birth and weaning weight and daily live weight gain associated to I. lamb with i. birth type j. sex and k. dam age,

$$
\begin{aligned}
& \mu=\text { Expected mean value, } \\
& a_{i}=\text { the effect of } i . \text { birth type }(i=1,2 ; \text { single, twin }), \\
& b_{j}=\text { the effect of } j . \text { sex }(j=1,2 ; \text { male, female }), \\
& c_{k}=\text { the effect of } k . \text { dam age }(2,3,4,5 \leq)
\end{aligned}
$$

$\mathrm{e}_{\mathrm{ijk} / \mathrm{l}}=$ the random residual error.

Statistical analyses were performed by using SAS statistical package program [13].

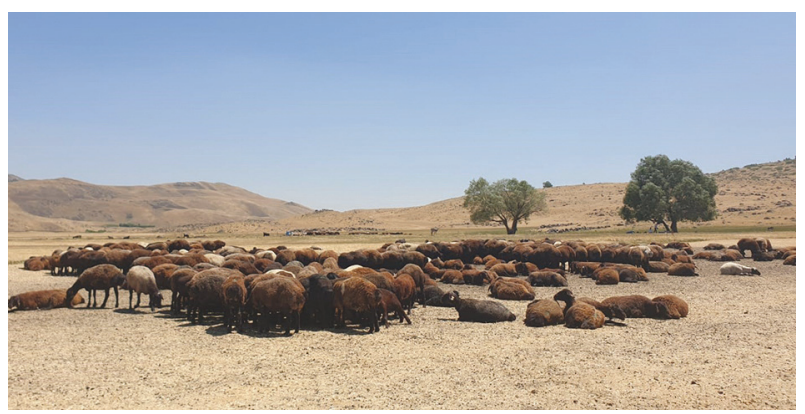

Figure 1. A herd of Morkaraman sheep.

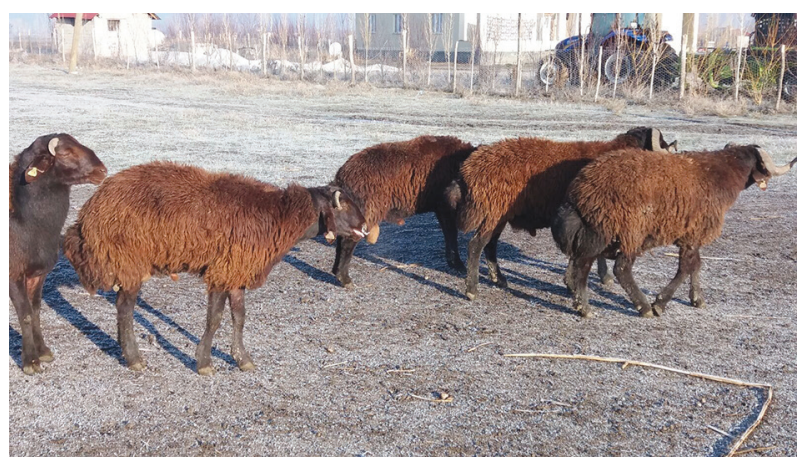

Figure 2. Morkaraman rams.

\section{Results and Discussion}

Averages for the birth weight, weaning weight and daily live weight gain of Morkaraman sheep

Averages for the birth weight, the weaning weight, and daily live weight gain of Morkaraman sheep are presented in the Table 1.

The means for birth and weaning weight of $90^{\text {th }}$ day were calculated as $3.79 \pm 0.01 \mathrm{~kg}$ and $29.30 \pm 0.10$ $\mathrm{kg}$. The average of daily live weight gain of lambs was found $272.8 \pm 0.01 \mathrm{~g}$ between birth and $90^{\text {th }}$ day. Means for some reproductive traits as lambing rate, infertility rate, survival rate at $90^{\text {th }}$ day weaaning, fecundity, and litter size were found as $92.2 \%, 7.8 \%, 97 \%, 1.11$, and 1.21 , respectively.

Effect of birth type and dam age on birth and weaning weight and daily live weight gain was found to be statistically significant $(p<0.001)$. Effect of gender on birth $(p<0.001)$ and weaning weight $(p<0.05)$ was found to be statistically significant. These findings on dam age were in agreement with those reported by Aygun and Bingol [2] and Kucuk [11].

The results of this research have shown that source of variation observed for birth and weaning weight in Morkaraman sheep may be the genetic and the environmental. As a result, it has been recommended to perform the improvement studies in mutton production from these sheep and these features can be used as a criterion to improve meat yield. The results of this re- 
search have been the basis for the scientific studies taking into account birth weight, weaning weight, and some reproductive traits of Morkaraman sheep. In particular, the source of observed variation in birth and weaning weight in Morkaraman sheep may be the genetic and the environmental.

Table 1. Means of birth and weaning weight, and daily live weight gain in Morkaraman lambs.

\begin{tabular}{|c|c|c|c|c|}
\hline & & $\begin{array}{c}\text { Birth Weight } \\
(\mathrm{kg})\end{array}$ & $\begin{array}{c}\text { Weaning } \\
\text { Weight (kg) }\end{array}$ & $\begin{array}{l}\text { Daily Live } \\
\text { Weight Gain } \\
\left(0-90^{\text {th }} \text { day, kg) }\right.\end{array}$ \\
\hline Factors & $\mathrm{n}$ & Mean & Mean & Mean \\
\hline Birth type & & $* * *$ & $* *$ & $* * *$ \\
\hline Single & 3776 & $4.00 \pm 0.01$ & $28.60 \pm 0.10$ & $0.280 \pm 0.01$ \\
\hline Twin & 1834 & $3.40 \pm 0.01$ & $29.61 \pm 0.16$ & $0.290 \pm 0.01$ \\
\hline Sex & & $* * *$ & $*$ & \\
\hline Male & 2787 & $3.87 \pm 0.01$ & $29.02 \pm 0.12$ & $0.285 \pm 0.01$ \\
\hline Female & 2823 & $3.73 \pm 0.01$ & $28.60 \pm 0.13$ & $0.282 \pm 0.01$ \\
\hline Dam age & & $* * *$ & $* * *$ & $* * *$ \\
\hline 2 & 1817 & $3.80 \pm 0.01^{\mathrm{a}}$ & $29.62 \pm 0.14^{b}$ & $0.290 \pm 0.01^{\mathrm{b}}$ \\
\hline 3 & 1222 & $3.79 \pm 0.01^{\mathrm{a}}$ & $29.60 \pm 0.20^{b}$ & $0.288 \pm 0.01^{b}$ \\
\hline 4 & 477 & $3.90 \pm 0.02^{\mathrm{ab}}$ & $29.40 \pm 0.33^{b}$ & $0.288 \pm 0.01^{b}$ \\
\hline $5 \leq$ & 2094 & $3.80 \pm 0.01^{\mathrm{a}}$ & $28.11 \pm 0.13^{b}$ & $0.280 \pm 0.01^{b}$ \\
\hline Overall & 5610 & $3.79 \pm 0.01$ & $29.30 \pm 0.10$ & $0.273 \pm 0.01$ \\
\hline
\end{tabular}

It has been suggested that the ram effect used in villages can be significant. In particular, the selection of ram must be considered for breeding in Morkaraman sheep. In order to obtain a more definite conclusion is required to detailed works in native sheep populations in Eastern Anatolia region of Turkey.

Detailed descriptions regarding the overall performances of Turkey's native breeds in local conditions are not sufficient. However, the improvement programs should be efficiently developed in livestock at direct breeders. Investigations should be conducted to identify the morphological and the physiological characteristics of native breeds under normal breeder conditions. By obtaining the more synthesis of this information, the more sensitive animal breeding programs and the policies can be developed $[4,7,10]$.

As a method, selection should be used for improvement of Morkaraman breed because of their high milk yield, and the growth and development properties of lambs. To increase the yield of indigenous breeds, a selection which will take into account the structure and yields must be applied. In selection, lamb yield and live weight gain should be emphasized.

Sheep husbandry is an industrial sector that they transforms the natural vegetation cover pasture and the pasture not used in the agriculture into the products such as meat, milk, and wool. There are breeds such as White Karaman, Morkaraman, Awassi, Dağlıç, Kıvırcık, and Karayaka among local sheep breeds of Turkey [8]. The results of this study will contribute to the scientific studies taking into account the greasy wool yield, the live weight after shearing, and the clean fleece percentage of Morkaraman ewes and the wool problems in the region. Even so, in order to obtain a more definite conclusion is required to detailed works in native sheep populations in Eastern Anatolia region of Turkey. The findings of this study have suggested that the ram effect used in villages can be significant. In particular, the source of the observed variation in the greasy wool weight may be the genetic and the environmental in Morkaraman sheep.

\section{Conclusion}

Studies about Morkaraman sheep breed have been mostly performed in the Eeastern Anatolia of Turkey. In order to obtain a more definite conclusion is required to detailed works in native sheep populations in Eastern Anatolia region of Turkey.

Small ruminant husbandry is indispensable and an important source of income for farmers in Muş province. Muş province is suitable for small ruminant breeding in terms of large pasture areas, water resources, and climate characteristics. It can be said that the province is rich in terms of underground and surface irrigation sources as well as a suitable land structure for the production of forage crops. Small ruminant husbandry is a major industrial sector in the Eastern Anatolia of Turkey and relies heavily on migrant and nomadic farm life. It has been suggested that the ram factor used in villages can be significant. In particular, the selection of ram must be considered for breeding in Morkaraman sheep.

The results of this research have shown that source of variation observed for birth and weaning weight in Morkaraman sheep may be the genetic and the environmental. As a result, it has been recommended to perform the improvement studies in mutton production from these sheep and these features can be used as a breeding criterion to improve meat yield.

\section{Acknowledgment}

This research has financially been supported by Republic of Turkey Ministry of Agriculture and Forestry, General Directorate of Agricultural Research and Policies as Morkaraman Sheep Breeding Sub-Project code: 49MOR2017-01. We thank for survey all breeders working in the sheep husbandry. We would like to emphasize my deep appreciation to the organizing committees of $1^{\text {st }}$ International Livestock Science Congress.

\section{Credit}

This study was presented in the $1^{\text {st }}$ International Livestock Science Congress, 31 Oct.-01Nov. 2019, Antalya, Turkey. 


\section{References}

1. Arslan M, Yılmaz O, Ateş CT (2003). Morkaraman ve Corriedalex Morkaraman (Fı) kuzularında büyüme. Yüzüncü Yıl Üniversitesi Veterinerlik Fakültesi Dergisi, 14(1): 46-49.

2. Aygün T, M Bingöl (1999). Akkaraman varyetesi Karakaş ve Norduz kuzularının doğum ağılıkları bakımından karşılaştrılması. Ege Üniv. Ziraat Fak., Uluslararası Hayvancılık' 99 Kongresi, 21-24 Eylül 1999, İzmir, 738-742.

3. Aygün T, Demir F (2014). Highland sheep husbandry and zoma life in Hakkari. Uluslararası Mezopotamya Tarım Kongresi, 2225 Eylül 2014, Diyarbakır, Abstract Book, s: 934-935.

4. Aygün T (2015). Serum FSH (Follicle Stimulating Hormone) concentrations in prepubertal female Norduz lambs. Ppresented at the 5th International Conference on Asia Agriculture and Animal (ICAAA), Madrid, Spain, June 15-16, 2015.

5. Bilgin ÖC, Esenbuğa N, Macit M, Karaoğlu M (2004). Morkaraman ve İvesi koyunlarında büyüme eğrisi özellikleri. 2. Genetik ve çevresel durum. Journal Applied Animal Research, 26: 7-12.

6. Erişir Z, Özbey O (2005). The Wool production characteristics in Morkaraman and Chios X Akkaraman $\left(F_{1}\right)$ and Kivircık $x$ Morkaraman $\left(F_{1}\right)$ crossbred sheep. Journal of Animal and Veterinary Advances, 4(3): 360-362.
7. Gürsu G, Aygün T (2014). Some characteristics of milk yield in Awassi ewes maintained at village conditions. Journal of Advanced Agricultural Technologies, 1(1): 19-23.

8. Inan I, Aygün T (2019). The body weight after shearing and the greasy wool yield of Red Karaman ewes at different raising conditions in Turkey. Journal of Advanced Agricultural Technologies, 6(2): 139-143.

9. Kayalık MŞ, Bingöl M (2015). All characteristics of Morkaraman sheep. Tüm yönleriyle Morkaraman koyunları. Iğdır Üniversitesi Fen Bilimleri Enstitüsü Dergisi, 5(2): 89-97.

10. Kaymakçı M (2010). Advanced Sheep Husbandry" "ileri Koyun Yetiştiriciliği," Ege University Press, Third Edition, Bornova, İzmir, Turkey.

11. Kucuk M (2004). Growth characteristics of Hamdani, Karakul and Morkaraman lambs in suckling period Indian Vet. J. 81: 172-175.

12. Öztürk Y, Odabaşıoğlu F (2011). The investigation of yield and morphological characteristics of Hamdani sheep in Van area: I. Various yield characteristics of sheep. "Van ve yöresinde Hamdani koyunlarının verimleri ve morfolojik özelliklerinin araştrılması: I. Koyunların çeşitli verim özellikleri," Yüzüncü YıI Üniversitesi Veteriner Fakültesi Dergisi, 22(2): 75-80.

13. SAS (2016). PC SAS User's Guide: Statistics. SAS Inst. cary. NC, USA. 